\title{
MINIREVIEW
}

\section{Amphibian metamorphosis as a model for studying the developmental actions of thyroid hormone}

TATA JAMSHED R

National Institute for Medical Research, The Ridgeway, Mill Hill, London NW7 1AA, U.K.

Tel: +44-181-9593666 Fax: +44-181-913 8583

E-mail:jtata@nimr.mrc.ac.uk

\section{ABSTRACT}

The thyroid hormones L-thyroxine and triiodo-Lthyronine have profound effects on postembryonic development of most vertebrates. Analysis of their action in mammals is vitiated by the exposure of the developing foetus to a number of maternal factors which do not allow one to specifically define the role of thyroid hormone (TH) or that of other hormones and factors that modulate its action. Amphibian metamorphosis is obligatorily dependent on TH which can initiate all the diverse physiological manifestations of this postembryonic developmental process (morphogenesis, cell death, re-structuring, etc.) in free-living embryos and larvae of most anurans. This article will first describe the salient features of metamorphosis and its control by TH and other hormones. Emphasis will be laid on the key role played by $\mathrm{TH}$ receptor (TR), in particular the phenomenon of TR gene autoinduction, in initiating the developmental action of TH. Finally, it will be argued that the findings on the control of amphibian metamorphosis enhance our understanding of the regulation of postembryonic development by $\mathrm{TH}$ in other vertebrate species.

Key words: Thyroid hormone, metamorphosis, postembryonic development, thyroid hormone receptor, autoinduction. 
Amphibian metamorphosis and thyroid hormone action

\section{INTRODUCTION}

Well before the chemical identification of L-thyroxine $\left(\mathrm{T}_{4}\right)$ and 3, 3' 5-triiodo-Lthyronine $\left(\mathrm{T}_{3}\right)$ as thyroid hormones, the secretions of thyroid gland were known to regulate growth and development in a variety of vertebrates[1,2]. The studies of Evans and colleagues in 1949 on the restoration of growth and maturation of the skeletal system in thyroidectomized and hypophysectomized neonatal rats established experimentally the growth and developmental action of $\mathrm{T}_{4}$ and its interaction with growth hormone. The demonstration that $\mathrm{T}_{4}$ is converted intracellularly to $\mathrm{T}_{3}$, which is considered to be the active form of thyroid hormone (TH), has made it easier to follow the biochemical and molecular events that underlie the cellular actions of thyroid hormone[2, 3, 5]. Observations on goitre, abnormal development and mental retardation in young children had indicated over two centuries ago the close relationship between thyroid hormone in foetal and prenatal human development and, especially, neuronal maturation[2, 4, 5]. As knowledge of the physiological and biochemical actions of thyroid hormone in different species and tissues progressed, a major characteristic of this hormone emerged, namely the multiplicity of its actions. The rapid advances in gene technology in the last two decades have revealed that thyroid hormone receptors (TRs) are highly conserved and it is generally accepted that the primary intracellular event is the interaction between TR and its ligand in the cell nucleus and that the diversity of actions of TH is generated by species- and tissue-specific factors and mechanisms[6-8]. Whereas the developmental, growthpromoting and metabolic actions of $\mathrm{TH}$ in postnatal and adult mammals can be analyzed experimentally with some degree of precision, the same is not possible for determining the role of the hormone in postembryonic and foetal development. The major reason for this obstacle lies in the transplacental transfer of $\mathrm{TH}$ to the developing mammalian organism and the multiple and complex interplay between thyroid and other hormones and growth factors during intrauterine development[9]. It has therefore become necessary to examine the developmental actions of $\mathrm{TH}$ in organisms in which fertilization occurs externally and the embryos are free-living. The obligatory requirement of thyroid hormone for amphibian metamorphosis, and its many similarities with mammalian postembryonic development, therefore offers a unique opportunity to explore its developmental actions in vertebrates[10, 11,53$]$. In this article I shall first describe the salient features of amphibian metamorphosis, followed by the role of $\mathrm{TH}$ in regulating morphogenesis, gene and biochemical re-programming and cell death and, finally, the significance of TR gene expression underlying these processes.

\section{Amphibian metamorphosis}

During the course of his studies on the nutritional requirements for the growth of frog tadpoles, Gudernatsch[12] found that some of the larvae that had been fed on extracts of mammalian thyroid glands underwent precocious metamorphosis spon- 
taneously[12]. Detailed analysis later of the functional role of the developing larval thyroid gland, and the availability of pure $\mathrm{T}_{4}$, confirmed that the process of metamorphosis was obligatorally dependent on thyroid hormone. By the 1950s much evidence had accumulated to show that the hormone provokes diverse and multiple morphological, physiological and biochemical responses in virtually every tissue of the amphibian tadpole[10, 13, 14]. Tab 1 lists some of the important responses to TH in different tissues of the pre-metamorphic tadpole, which range for example from de novo morphogenesis, re-patterning, functional re-programming and partial and total regression of most tissues. Before extending this article to the biochemical and molecular mechanisms underlying the developmental actions of thyroid hormone, it is useful to briefly consider the special characteristics of the role of $\mathrm{TH}$ in amphibian metamorphosis.

\section{Absolute requirement for $\mathrm{TH}$}

Surgical, chemical or radiation-induced removal or ablation of the thyroid gland of an early tadpole will permanently prevent metamorphosis. The thyroidectomized larva will continue to grow (under the influence of growth hormone and other growthpromoting factors) without it acquiring the adult phenotype. Administration of $\mathrm{T}_{4}$ or $\mathrm{T}_{3}$ at any stage after thyroidectomy will cause the resumption of the arrested differentiation and lead to metamorphosis[14]. This finding clearly establishes the obligatory requirement of $\mathrm{TH}$, as well as indicating that the genetic programme for postembryonic development is stable and not determined temporally. A systematic study in which different stages of Xenopus embryos and tadpoles were exposed to exogenous $\mathrm{T}_{3}$, and a number of indices of morphological and biochemical responses measured, showed that the competence was established well before the tadpole's thyroid gland had developed functionally[15]. This finding is of particular relevance in understanding the role of TH receptor since it means that TR is expressed constitutively early in development.

\section{Diversity of genetic programmes under TH control}

Tab 1 illustrates that no two tissues of the amphibian larva exhibit the same response to TH. Some of the responses are the manifestation of a new genetic programme activated by the hormone, whereas others represent the acceleration or slowing down of the expression of a programme that had already been initiated before the action of the hormone[16]. What is of particular interest are the direct response genes, namely those whose transcription is initiated in the presence of inhibitors of protein synthesis. Using a "gene screen" procedure, Brown, Shi and their colleagues have been able to classify genes in Xenopus tadpoles which are up- or down-regulated by $\mathrm{T}_{3}$ and those that are direct response genes[17, 18]. Most direct response genes are up-regulated during metamorphosis, even in tissues programmed for total tissue regression. 
Tab 1. Diversity of morphological and biochemical responses to thyroid hormone during amphibian metamorphosis

\begin{tabular}{|c|c|c|}
\hline Tissue & \multicolumn{2}{|c|}{ Response } \\
\hline & Morphological & Biochemical \\
\hline Brain & $\begin{array}{l}\text { Re-structuring; axon guidance } \\
\text { and growth; cell turnover }\end{array}$ & $\begin{array}{l}\text { Cell division; apoptosis; } \\
\text { protein synthesis }\end{array}$ \\
\hline Liver & $\begin{array}{l}\text { Functional differentiation; } \\
\text { re-strucuring }\end{array}$ & $\begin{array}{l}\text { Induction of albumin and } \\
\text { urea cycle enzymes; larval } \\
\text { adult haemoglobin switch }\end{array}$ \\
\hline Eye & $\begin{array}{l}\text { Re-positioning; new retinal } \\
\text { neurones; altered lens }\end{array}$ & $\begin{array}{l}\text { Visual pigment switch; } \\
\text { induction of } \beta \text {-crystallin }\end{array}$ \\
\hline Skin & $\begin{array}{l}\text { Re-structuring; keratinisation; } \\
\text { granular gland formation }\end{array}$ & $\begin{array}{l}\text { Induction of collagen, } \\
63 \mathrm{kDa} \text { keratin, magainin }\end{array}$ \\
\hline Limb bud, lung & $\begin{array}{l}\text { De novo morphogenesis of } \\
\text { bone, skin, muscle, nerve, etc. }\end{array}$ & $\begin{array}{l}\text { Cell proliferation; gene } \\
\text { expression }\end{array}$ \\
\hline Tail, gills & $\begin{array}{l}\text { Total tissue regression and } \\
\text { removal }\end{array}$ & $\begin{array}{l}\text { Programmed cell death; } \\
\text { induction of lytic enzymes }\end{array}$ \\
\hline Intestine, pancraes & $\begin{array}{l}\text { Major re-modelling } \\
\text { of tissues }\end{array}$ & $\begin{array}{l}\text { Newstructural and } \\
\text { fuctional constituents }\end{array}$ \\
\hline Immune system & $\begin{array}{l}\text { Re-distribution of immune } \\
\text { cell populations }\end{array}$ & $\begin{array}{l}\text { Aquisition of new } \\
\text { immunocompetence }\end{array}$ \\
\hline Muscle & $\begin{array}{l}\text { Growth, differentiation, } \\
\text { apoptosis }\end{array}$ & $\begin{array}{l}\text { Induction of myosin } \\
\text { heavy chain }\end{array}$ \\
\hline
\end{tabular}

\section{TH acts directly and locally}

Transplantation studies with early tadpole tissues had already indicated that changing the location of tissue or organ did not alter its response later on to endogenous or exogenous $\mathrm{TH}[14]$, thus proving that the hormone does not determine the developmental programme but only initiates it. More convincing evidence for a non-systemic action of $\mathrm{TH}$ comes from tissue culture experiments which show that the hormone acts directlyon each target tissue to set into motion the same predetermined genetic programme as in whole tadpoles. This has been demonstrated for organ cultures of larval skin, liver, limb buds, intestine and tail[19, 20]. In a study in which the tail and limb buds from the same tadpole were cultured in parallel, $\mathrm{T}_{3}$ induced morphogenesis in one tissue but cell death in the other[19], thus demonstrating that the hormone initiates diametrically opposite developmental changes in these two tissues. 


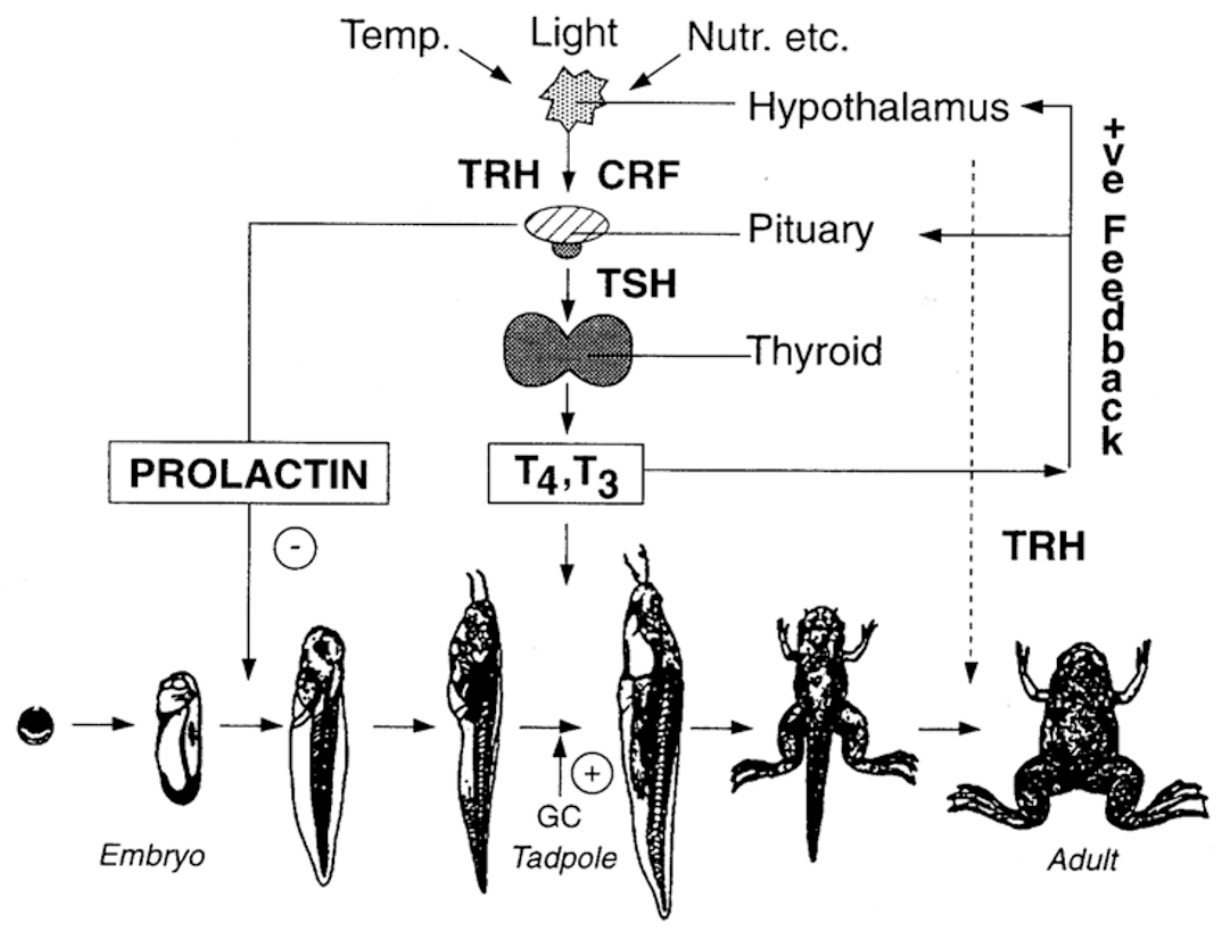

Fig 1. Schematic representation of the hormonal regulation of amphibian metamorphosis. In response to environmental cues, the dormant thyroid gland of the tadpole is activated to produce the thyroid hormones $\mathrm{T}_{4}$ and $\mathrm{T}_{3}$ by the hypothalamic and pituitary hormones TRH, CRF and TSH. Thyroid hormone (TH) is obligatorily required to initiate and maintain the metamorphosis, its action being potentiated by glucocorticoid hormone and retarded by prolactin. Nutr., nutritional factors; TRH, thyrotrophin-releasing hormone; $\mathrm{CRF}$, cortcotrophin-releasing factor; $\mathrm{TSH}$, thyoid stimulating hormone; $\mathrm{T}_{4}$, L-thyroxine; $\mathrm{T}_{3}$, triiodo-L-thyronine; GC, glucocorticoid hormone.

\section{TH action can be modulated by other hormones}

Although the culture studies confirmed that TH acts directly on its target tissues, it is also known that other hormones, factors released by neighbouring tissues or environmentally transmitted signals can modify the response of a given tissue to $\mathrm{TH}[10,11]$. Among important endocrine factors are glucocorticoid hormone, CRF (corticotrophin-releasing hormone) and prolactin (PRL) (see Fig 1). Exogenous glucocorticoids, ACTH and CRF are known to potentiate, while PRL blocks both natural and TH-induced metamorphosis[21, 22]. These hormones will also accel- 
Amphibian metamorphosis and thyroid hormone action

erate or inhibit the action of $\mathrm{TH}$ in cultures of individual tissues. Although the interplay between TH and PRL and glucocorticoids and the cellular and molecular mechanisms of this interplay are poorly understood, the modulation of $\mathrm{TH}$ action by glucocorticoids and PRL has provided a useful tool in analyzing the action of $\mathrm{TH}$, especially in organ cultures of tadpole tissues.

\section{Programmed cell death is an important feature of amphibian metamorphosis}

A major characteristic of metamorphosis is the restructuring and further differentiation of tissues such as the brain, limb buds, intestine and pancreas[16, 23]. The first studies on isolated tadpole tails in culture and the use of inhibitors of protein synthesis demonstrated that cell death is dependent on the de novo synthesis of new proteins[24]. This requirement for new protein synthesis for the onset of apoptosis is a common feature of programmed cell death during development. With the recent advances in the characterization of genes encoding cell death and cell survival proteins, the identification of hormonally regulated "early" proteins responsible for initiating apoptosis is now a most interesting prospect.

\section{Thyroid hormone receptors}

Thyroid hormone receptors are the key to understanding how the hormone controls its diverse metabolic and developmental functions, including metamorphosis. Although transport across the cell membrane and interactions with cytoplasmic proteins determine the dynamics of $\mathrm{TH}$ distribution within the target cell, it is the interaction with TRs in the cell nucleus which is the crucial step that initiates the molecular and biochemical progression leading to the physiological response to the hormone.

General characteristics of thyroid hormone receptors

TRs are members of an evolutionarily highly conserved supergene family of steroid/thyroid hormone/retinoid nuclear receptors that function as ligand-inducible transcription factors[6-8, 25-27]. In all vertebrates examined so far they are encoded by two genes termed TR $\alpha$ and $\beta$ from which are generated multiple isoforms according to the tissue and species. The modular structure of nuclear receptors comprising the N-terminus, DNA-binding and ligand-binding domains is now well-known. TRs belong to the subgroup that includes nuclear receptors for retinoic and 9-cis retinoic acids (RARs and RXRs, respectively), vitamin D3 (VDR) and peroxisome proliferators (PPAR)[7]. Unliganded TRs are constitutively located in the nucleus as components of chromatin and, unlike steroid receptors, the ligand is not involved in their translocation from the cytoplasm into the nucleus[27]. It is generally accepted that liganded TRs activate the transcription of their target genes by interacting with thyroid response elements (TREs) in their promoters, the most common motif being AGGTCAnnnnAGGTCA and known as direct repeat plus $4(\mathrm{DR}+4)[7,25]$. 
Interestingly, the same direct repeat separated by $1,2,3$ or 5 nucleotides acts as response elements for RXR, PPAR, RAR and VDR, respectively. The mechanism by which TR regulates transcription is not fully understood, but three important features of the receptor are relevant. First, unlike other nuclear receptors, unliganded TR acts as a strong repressor, the repression being relieved by the ligand[7, 28, 29]. Second, although TR monomer and homodimer can interact with TRE, the physiologically active form is the heterodimer formed with RXR, a property also shared by other members of its subgroup of nuclear receptors[6, 7, 25]. Third, two groups of proteins that have recently been identified as co-repressors (CoR) or co-activators ( $\mathrm{CoAc}$ ) are thought to be essential for the transactivation function of the receptor[7, 29, 30]. The role of hormone binding to the ligand-binding domain of TR would be to cause the dissociation of CoR from its inactive complex with the receptor while at the same time facilitating the recruitment of CoAc to form a transactivational complex[7]. Also recently, much interest has been generated by the finding that co-repressors and co-activators have histone acetylase or deacetylase activities[31, 32]. It will not be surprising that more components participating in such complexes and structurally organized as chromatin[33, 34] are discovered in the near future. These considerations are important for understanding the role of $\mathrm{TH}$ in regulating amphibian metamorphosis, since it is quite likely that different combinations of nuclear receptors, transcription factors, co-repressors, co-activators and other chromatin constituents may determine the diversity of tissue-specific manifestation of differential gene expression programme seen in amphibian metamorphosis (see Tab 1).

\section{Developmental regulation of amphibian TRs}

In Xenopus tadpoles normal metamorphosis does not begin until the larval thyroid gland becomes functional, which can be about 6 weeks after fertilization. The onset and rapid acceleration of metamorphosis correlates well with the build-up of circulating $\mathrm{T}_{3}[16,35]$. The fact that competence to respond to exogenous $\mathrm{TH}$ is established as early as 1 week after fertilization[15] means that functional TR is present well before the secretion of the hormone. Hence it was not surprising that both TR $\alpha$ and $\beta$ mRNA and protein can be detected in most tissues of the early premetamorphic larvae[22, 36-40], indicating the constitutive expression of TRs at low levels. There is also strong correlation between the accumulation of TR mRNA and protein and the rising levels of TH. Upon completion of metamorphosis the concentrations of all three constituents decline very sharply. This correlation raised the question as to whether the hormone itself regulates the expression of its own receptor genes.

\section{Autoregulation of TRs during metamorphosis}

Biochemical, in situ hybridisation and immunocytochemical analyses of TR mR- 
NAs and proteins have clearly shown that exogenous TH can precociously upregulate TR gene expression[36-41]. The autoinduction of TR correlates well with the increased sensitivity of Xenopus tadpoles to $\mathrm{T}_{3}$ as development progresses and the process occurs in all tissues irrespective of whether or not they undergo de novo morphogenesis, total regression or re-structuring. The upregulation of TR genes is among the most rapid responses to $\mathrm{TH}$ in amphibia, is more marked for the $\beta$ than the a gene and is the result of direct activation of their transcription[16, 17, 22, 35]. It can also be reproduced in Xenopus cell lines with similar kinetics to those seen in whole tadpoles[35, 42, 43]. The advantage of studying receptor autoinduction in tissue culture is not only a greater precision of establishing its kinetics but it also allows one to investigate the mechanism of the process by DNA transfection.

In order to determine if TR interacts with its own gene, it was first necessary to identify TRE sequences in the promoter of the amphibian TR genes. The promoter of Xenopus TR gene has been cloned[44, 45] and several regulatory elements identified, including two $\mathrm{DR}+4$ sites upstream of the transcription initiation site[45]. Mutational analysis and transfection of two Xenopus cell lines (XTC-2 and XL-177) with promoter constructs showed that both sites responded to $\mathrm{T}_{3}$. Furthermore, overexpression of unliganded TRs reduced the basal transcriptional activities of these cells which was overcome by $\mathrm{T}_{3}$, as in mammalian cells[7, 28, 29]. Using different isoforms of recombinant TRs and RXRs in electrophoretic mobility shift assays Machuca and collaborators[45] were able to demonstrate that TR-RXR heterodimers, but not TR monomers or homodimers, specifically interacted with both TREs in the promoter of the Xenopus TR $\beta$ gene, thus suggesting that the heterodimer could regulate the transcription of TR.

Further evidence that TRs could act directly on the promoters of their own genes has come from studies on dominant-negative (d-n) TRs in whole Xenopus tadpole tissues and cell lines[46]. A large number of $\mathrm{d}-\mathrm{n}$ TR $\beta 1$ mutant receptors in man, associated with the syndrome of generalized thyroid hormone resistance, have been shown to bind TREs, but not TH, and inhibit transactivation by wild-type TRs in a dominant-negative manner[7, 16, 25, 47]. It is therefore significant that human mutant TR $\beta$ s and a synthetic mutant Xenopus TR $\beta$ were able to inhibit autoinduction of wild-type TR $\beta$ when transfected into XTC-2 cells[46]. The strength of the dominant-negative effect of the mutant TRs correlated well with heterodimerization with RXR and the binding of the heterodimers with various TREs. More importantly, transfection of tadpole tail muscle in vivo[48] showed that d-n mutant TRs prevented wild-type TR $\beta$ autoinduction in premetamorphic Xenopus tadpole tissues. These results now lead to the important question of how relevant is the autoinduction of TR to the process of metamorphosis itself. While awaiting the outcome of experiments designed to answer the above question there is good indirect evidence from two separate observations of an intimate relationship between TR gene expression and the regulation of amphibian metamorphosis by thyroid hormone. First,there is a good correlation between the inhibition and potentiation of 
metamorphosis by PRL and glucocorticoid, respectively, and the inhibition or enhancement of autoinduction of TR and RXR genes in several tadpole tissues during natural or $\mathrm{T}_{3}$-induced metamorphosis[19, 39, 41, 49]. This correlation is particularly marked for the antagonism between $\mathrm{TH}$ and $\mathrm{PRL}$, as can be discerned from Tab 2. PRL blocks the upregulation of both TR $\alpha$ and $\beta$ mRNAs induced by $\mathrm{T}_{3}$, but does not affect the constitutive expression of the receptor genes, as determined by different analytical procedures in whole premetamorphic tadpoles and in organ cultures. The conclusion that TR autoinduction is necessary for the activation of downstream TR target genes is supported by the inhibition by PRL of the activation of the downstream genes encoding albumin, $63 \mathrm{kDa}$ keratin and stromelysin-3 genes[39, 49]. Interestingly, the action of PRL is specific for $\mathrm{TR}$ since $\mathrm{T}_{3}$ lowered the accumulation of RXR mRNA but PRL did not block this action of $\mathrm{T}_{3}$ as it does for TRs. On the other hand, the synthetic glucocorticoid dexamethasone which potentiates $\mathrm{T}_{3}$-induced metamorphosis elevates the levels of both TR and RXR mRNAs but PRL would only suppress that of TR when all three hormones are added to organ cultures of premetamorphic Xenopus tadpole tails[49]. The mechanism of the anti-metamorphic action of PRL in amphibia remains unknown, although recently some progress has been made in elucidating the molecular action of this hormone in mammals[50].

Tab 2. Relative accumulation of TR $\alpha$ and $\beta$ mRNAs in premetamorphic Xenopus tadpoles treated with $\mathrm{T}_{3}$ and prolactin (PRL)

\begin{tabular}{lrr}
\hline Treatment & \multicolumn{2}{c}{ Relative Units } \\
\cline { 2 - 3 } & TR $\alpha$ & TR $\beta$ \\
\hline None & 505 & 24 \\
$\mathrm{~T}_{3}$ & 1290 & 368 \\
$\mathrm{~T}_{3}+$ PRL & 799 & 10 \\
PRL & 405 & 43 \\
\hline
\end{tabular}

Batches of 20 stage 50 Xenopus tadpoles were treated with 2 $\times 10^{-9} \mathrm{M} \mathrm{T}_{3}$ with or without $0.1 \mathrm{iu} \mathrm{PRL/ml} \mathrm{for} 4 \mathrm{~d}$ before relative amounts of TR mRNAs were measured in total larval RNA by RNase protection assay. See ref. [39] for details.

Another indirect indication that the autoinduction of TR genes is closely linked to amphibian metamorphosis comes from comparative studies of $\mathrm{TR}$ in neotenic amphibia, i.e. those that do not undergo metamorphosis spontaneously[35, 36, 51]. Facultatively neotenic amphibia such as the mexican axolotl or the tiger salamander (Ambystoma), which do not go through metamorphosis normally, will do so if exogenous TH is given, while obligatory neotenic amphibia such as Necturus and Proteus do not respond to TH. As can be seen in Tab 3, low levels of TR mRNAs can be detected in Ambystoma tissues which can be upregulated by the administration of $\mathrm{T}_{3}$ in parallel with a partial metamorphic response (loss of tail fin, growth of limbs, excretion of nitrogen as urea), as in Xenopus. In contrast, only TR a transcripts 
could be detected in tissues of Necturus in which $\mathrm{T}_{3}$ failed to upregulate the expression of TR $\alpha$ or $\beta$ mRNA.

\section{Amphibian metamorphosis and mammalian postembryonic develop- ment}

Unlike the abrupt changes in response to thyroid hormone that occur during amphibian metamorphosis, mammalian postembryonic or foetal development is characterized by a relatively slow and continuous progression of developmental changes during which the foetus is exposed to multiple hormonal and other developmental signals of both maternal and foetal origin[2, 9, 52, 53]. Nevertheless, there are some remarkable similarities between the developmental changes induced by thyroid hormone during metamorphosis (Tab 1 ) and those seen during intrauterine and perinatal development of mammals (Tab 4). Good examples of the similarities are the switch from larval or foetal to adult haemoglobin, induction of albumin genes, skin keratinization, bone and limb maturation and the appearance of urea cycle enzymes.

Tab 3. Association between TR autoinduction and response to thyroid hormones $\left(\mathrm{T}_{3}, \mathrm{~T}_{4}\right)$ of spontaneously metamorphosing and facultatively or obligatorily neotenic amphibia

\begin{tabular}{|c|c|c|c|c|}
\hline \multirow{2}{*}{ Specise } & \multirow{2}{*}{ Metamorphosis } & \multirow{2}{*}{$\begin{array}{c}\text { Endogenous } \\
\mathrm{T}_{3}, \mathrm{~T}_{4}\end{array}$} & \multicolumn{2}{|c|}{ TR Genes } \\
\hline & & & Expressed* $^{*}$ & Autoinduced\# \\
\hline Xenopus & Spontaneous & Yes & Yes & Yes \\
\hline Ambystoma & $\begin{array}{l}\text { Facultatively } \\
\text { neotenic }\end{array}$ & No & Yes & Yes \\
\hline Necturus & $\begin{array}{l}\text { Obligatorily } \\
\text { neotenic }\end{array}$ & Yes & Yes & No \\
\hline
\end{tabular}

* Only TR a detectable in Necturus \# By exogenous TH

Tab 4. Some examples of mammalian postembryonic developmental expression of genes and processes specifying the adult phenotype

\begin{tabular}{ll}
\hline \multicolumn{1}{c}{ Process } & \multicolumn{1}{c}{ Genes and tissues } \\
\hline Mene switching & $\begin{array}{l}\text { a -Foetoprotein to albumin and foetal to adult } \\
\text { haemoglobin in liver; immunoglobulin genes } \\
\text { Maturation and differentiation of limb, bone, lung, skin }\end{array}$ \\
Neurogenesis & $\begin{array}{l}\text { Neural cell turnover, axonal growth, aquisition } \\
\text { of new sensory functions }\end{array}$ \\
Tissue re-modelling & $\begin{array}{l}\text { Keratinization of epidermis; connective tissue } \\
\text { formation; re-structuring of intestine }\end{array}$ \\
New functions & $\begin{array}{l}\text { Nitrogen metabolism and urea synthesis } \\
\text { new cell adhesion molecules }\end{array}$ \\
Cell death & $\begin{array}{l}\text { Removal of tissues or organs by induction of } \\
\text { lytic enzymes and expression of cell death and } \\
\text { survival genes; digit formation }\end{array}$ \\
\hline
\end{tabular}


Prominent among the similarities are the parallelism between structural and functional changes that occur in the larval or foetal brain and limb development during amphibian metamorphosis and mid- to late foetal (or perinatal) development in mammals[2, 9, 54-58], where TH also plays an important role. Perhaps the best documented illustration of the importance of $\mathrm{TH}$ during human foetal or perinatal development is cretinism or severe mental retardation and abnormal skeletal differentiation caused by a deficiency of $\mathrm{TH}$ at mid- late stages of pregnancy[4, 5, 59, 60]. Experimental hypothyroidism induced in rodents during this period has been shown to cause severe impairement of many sensory functions (taste, hearing, vision) whose normal establishment coincides with a substantial surge in the level of $\mathrm{TH}$ in foetal blood. Tissue culture studies have shown a direct action of $\mathrm{TH}$ on the differentiation of several types of neuronal cells[4, 8, 54, 59, 60]. Recently, Forrest and his colleagues have demonstrated a deficient hearing ability in mice in which the TR $\beta$ gene had been "knocked-out" by homologous recombination[61]. It is therefore most significant that TH exerts a strong influence on olfactory and optical patterning and function during amphibian metamorphosis $[56,62]$. Also, in the context of autoinduction of TRs during amphibian metamorphosis, it is equally significant that the level of TRs increases in human foetal tissues during the period of gestation coinciding with the rapid rise in foetal TH levels[53].

Finally, an intriguing question to consider is to determine if the action of $\mathrm{TH}$ in mammalian foetal development is retarded or potentiated by some other factor(s), similar to the interplay between PRL, glucocorticoid and $\mathrm{TH}$ in metamorphosis. While the maturationl influences of glucocorticoids is known for mammalian perinatal period, virtually nothing is known about the possible antagonism between PRL and $\mathrm{TH}$ in foetal development. It is worth noting that the mammalian foetus is exposed during the second half of gestation to extraordinarily high concentrations of placental lactogen, the product of a PRL-like gene, followed by an abrupt fall in its concentration $[9,52,53,63]$. This fact raises several important questions concerning the major role of placental lactogen in foetal development as, for example, what are the factors regulating its production, its receptors in foetal tissues and its biochemical and molecular actions. It would be particularly relevant, in the light of the discussion in this article about hormonal interactions during amphibian metamorphosis, to resolve these questions if we are to better understand the mechanisms underlying the timing and acquisition of the adult phenotype in the crucial period of late foetal and perinatal development.

\section{ACKNOWLEDGEMENT}

I am particularly grateful to all my laboratory colleagues mentioned in references [19, 35, 38, 45, 46, 49] whose work has inspired much of this article. I would also like to thank Mrs. Ena Heather for help in preparing the manuscript. 
Amphibian metamorphosis and thyroid hormone action

\section{REFERENCES}

[1] Pitt-Rivers R, Tata JR. The Thyroid Hormones. Pergamon Press: London 1959.

[2] DeGroot LJ, Larsen PR, Hennemann G. The Thyroid and its Diseases. Churchill Livingstone: New York 1996.

[3] Oppenheimer JH, Samuels HH (eds).Molecular Basis of Thyroid Hormone Action. Academic Press: New York 1983.

[4] Dussault JH, Ruel J. Thyroid hormones and brain development. Ann Rev Physiol 1987; 49:32134.

[5] Delong GR, Robbins J, Condliffe PG (eds). Iodine and the Brain. Plenum Press: New York 1989.

[6] Mangelsdorf DJ, Evans RM. The RXR heterodimers and orphan receptors. Cell 1995; 83:841850 .

[7] Chatterjee VKK, Clifton-Bligh RJ, Matthews C. The steroid hormone superfamily of receptors. In: Rumsby G, Farrow SM. eds. Molecular Endocrinology. Genetic analysis of hormones and their receptors. Bios: Oxford 1997:73-101.

[8] Tata JR. Hormonal Signaling and Postembryonic Development. Springer: Heidelberg 1998.

[9] Baulieu EE, Kelly PA. Hormones. From Molecules to Disease. Hermann: Paris 1990.

[10] Gilbert LI, Frieden E (eds). Metamorphosis: A Problem in Developmental Biology. Plenum Press: New York 1981.

[11] Gilbert LI, Tara JR, Atkinson BG (eds). Metamorphosis. Postembryonic Reprogramming of Gene Expression in Amphibian and Insect Cells. Academic Press: San Diego 1996.

[12] Gudernatsch JF. Feeding experiments on tadpoles. Arch Entwicklungsmech Organ $1912 ; 35$ :457-83.

[13] Weber R. Biochemistry of amphibian metamorphosis. In: Weber R. ed. The Biochemistry of Animal Development. Academic Press: New York 1967:227-301.

[14] Etkin W, Gilbert LI (eds). Metamorphosis - A Problem in Developmental Biology. AppletonCentury- Crofts: New York 1968.

[15] Tara JR. Early metamorphic competence of Xenopus larvae. Dev Biol-1968; 18:415-40.

[16] Tata JR. Hormonal signaling and amphibian metamorphosis. Adv Dev Biol 1997; 5:237-74

[17] Shi YB. Thyroid hormone-regulated early and late genes during amphibian metamorphosis. In: Gilbert LI, Tara JR, Atkinson BG. eds. Metamorphosis. Postembryonic Reprogramming of Gene Expression in Amphibian and Insect Cells. Academic Press: San Diego 1996:505-38.

[18] Brown DD, Wang Z, Furlow JD, Kanamori A, Schwartzman RA, Remo BF, Pinder A. Thyroid hormone-induced tail resorption program during Xenopus laevis metamorphosis. Proc Natl Acad Sci USA 1996; 93:1924-9.

[19] Tata JR, Kawahara A, Baker BS. Prolactin inhibits both thyroid hormone-induced mophogenesis and cell death in cultured amphibian larval tissues. Dev Biol 1991; 146:72-80.

[20] Ishizuya-Oka A, Shimozawa A. Induction of metamorphosis by thyroid hormone in anuran small intestine cutured organotypically in vitro. In Vitro Cell Dev Biol 1991; 274:853-85721.

[21] Kikuyama S, Kawamura K, Tanaka S, Yamamoto, K. Aspects of amphibian metamorphosis. Hormonal control. Int Rev Cytol 1993; 145:105-48.

[22] Tata JR. Homonal interplay and thyroid hormone receptor expression during amphibian metamorphosis. In: Gilbert LI, Tara JR, Atkinson BG.eds. Metamorphosis. Postembryonic Reprogramming of Gene Expression in Amphibian and Insect Cells. Academic Press: San Diego 465-503.

[23] Tara JR. Hormonal regulation of programmed cell death during amphibian metamorphosis. Biochem Cell Biol 1994; 72:581-8.

[24] Tara JR. Requirement for RNA and protein synthesis for induced regression in organ culture. Dev Biol 1996; 13:77-94. 
[25] Yen PM, Chin WW. New advances in understanding the molecular mechanisms of thyroid hormone action. Trends Endocrin Metab 1994; 5:65-72.

[26] Laudet V, Hänni C, Coll J, Catzeflis F, Stéhelin D. Evolution of the nuclear receptor gene superfamily. EMBO J 1992; 11:1003-101327.

[27] Parker M (ed) Nuclear Hormone Receptors. Academic Press: London 1991.

[28] Baniahmad A, Tsai SY, O'Malley BW, Tsal MJ. Kindred thyroid hormone receptor is an active and constitutive silencer and a repressor for thyroid hormone and retinoic acid responses. Proc Natl Acad Sci USA 1992; 89:10,633-10,63729.

[29] Hörlein AJ, Näär AM, Heinzel T, Torchia J, Gloss B, Kurokawa R, Ryan A, Kamel Y, Söderström M, Glass CK, Rosenfeld MG. Ligand-independent repression by the thyroid hormone receptor mediated by a nuclear receptor co-repressor. Nature 1995; 377:397-404.

[30] Nagy L, Kao HY, Chakravarti D, Lin R, Hassig CA, Ayer DE, Schreiber SL, Evans RM. Nuclear receptor repression mediated by a complex containing SMRT, Sin3 and histone deacetylase. Cell 1997; 89:373-80.

[31] Orgyzko VV, Schlitz RL, Russanova V, Howard BH, Nakatani Y. The transcriptional coactivators p300 and CBP are histone acetyltransferases. Cell 1996; 87:953-9.

[32] Alland 1, Muhle R, Hou H Jr, Potes J, Chin L, Screiber-Agus N, DePinho RA. Role for N-Cor and histone deacetylase in Sin3-mediated transcriptional repression. Nature 1997; 387:49-55.

[33] Pazin MJ, Kadonaga. What's up and down with histone deacetylation and transcription? Cell 1997; 89:325-8.

[34] Wong J, Patterton D, Imhof A, Guschin D, Shi YB, Wolffe AP. Distinct requirements for chromatin assembly in transcriptional repression by thyroid hormone receptor and histone deacetylase. EMBO J 1998; 17:520-34.

[35] Tata JR, Baker BS, Machuca I, Rabelo EML, Yamauchi K. Autoinduction of nuclear receptor genes and its significance. J Steroid Biochem Molec Biol 1991; 46:105-19.

[36] Yaoita Y, Brown DD. A correlation of thyroid hormone gene receptor expression with amphibian metamorphosis. Genes Develop 1990; 4:1917-24.

[37] Kawahara A, Baker BS, Tata JR. Developmental and regional expression of thyroid hormone receptor genes during Xenopus metamorphosis. Development 1991; 112:933-43.

[38] Fairclough L, Tara JR. An immunocytochemical analysis of thyroid hormone and $\beta$ proteins during natural and thyroid hormone-induced metamorphosis in Xenopus. Dev Growth Differen 1997; 39:273-83.

[39] Baker BS, Tata JR. Prolactin prevents the autoinduction of thyroid hormone receptor mRNAs during amphibian metamorphosis. Dev Biol 1992; 149:463-7.

[40] Eliceiri B, Brown DD. Quantitation of endogenous thyroid hormone receptors $a$ and $\beta$ during embryogenesis and metamorphosis in Xenopus laevis. J Biol Chem 1994; 269:24459-65.

[41] Rabelo EML, Baker B, Tata JR. Interplay between thyroid hormone and estrogen in modulating expression of their receptor and vitellogenin genes during Xenopus metamorphosis. Mech Develop 1994; 45:49-57.

[42] Kanamori A, Brown DD. The regulation of thyroid hormone $\beta$ genes by thyroid hormone in Xenopus laevis. J Biol Chem 1992; 267:739-45.

[43] Machuca I, Tata JR. Autoinduction of thyroid hormone receptor during metamorphosis is reproduced in Xenopus XTC-2 cells. Molec Cell Endocr 1992; 87:105-13.

[44] Ranjan M, Wong J, Shi YB. Transcriptional repression of Xenopus TR $\beta$ gene is mediated by a thyroid hormone response element located near the start site. J Biol Chem 1994; 269:24699-705.

[45] Machuca I, Esslemont G, Fairclough L, Tata JR. Analysis of structure and expression of the Xenopus thyroid hormone receptor $\beta(\mathrm{xTR} \beta)$ gene to explain its autoinduction. Mol Endocrinol 1995; 9:96-108.

[46] Ulisse S Esslemont, G Baker BS, Chatterjce VKK, Tata JR. Dominant-negative mutant thyroid hormone receptors prevent transcription from Xenopus thyroid hormone receptor $\beta$ gene promoter 


\section{Amphibian metamorphosis and thyroid hormone action}

in response to thyroid hormone in Xenopus tadpoles in vivo. Proc Natl Acad Sci USA 1996; 93:1205-9.

[47] Refetoff S, Weiss RE, Usala SJ. The syndromes of resistance to thyroid hormone. Endocrin Re v 1993; 14:348-99.

[48] De Luze A, Sachs L, Demeneix B. Thyroid hormone-dependent transcriptional regulation of exogenous genes transferred into Xenopus tadpole tail muscle in vivo. Proc Natl Acad Sci USA 1993; 90:7322-6.

[49] Iwamuro S, Tata JR. Contrasting patterns of expression of thyroid hormone and retinoid X receptor genes during hormonal manipulation of Xenopus tadpole tail regression in culture. Molec Cell Endocrinol 1995; 113:235-43.

[50] Clevenger CV, Medaglia MV. The protein tyrosine kinase $\mathrm{p}^{59 y^{n}}$ is associated with prolactin (PRL) receptor and is activated by PRL stimulation of T-lymphocytes. Mol Endocrinol 1994; 8:674-81.

[51] Safi R, Begue A, Hanni C, Stehelin D, Tata HR, Laudet V. Thyroid hormone receptor genes of neotenic amphibia. J Mol Evol 1997; 44:595-604.

[52] Casey ML, MacDonald PC (1998) Endocrine changes of pregnancy. In: Wilson JD, Foster DW, Kronenberg HM, Larsen PR. eds. Williams Textbook of Endocrinology. WB Saunders Co: Philadelphia 1998:1259-71.

[53] Fisher DA. Endocrinology of fetal development. In: Wilson JD, Foster DW, Kronenberg HM, Larsen PR. Eds.Williams Textbook of Endocrinology. WB Saunders Co: Philadelphia 1998:1273-301.

[54] Tata JR. Brain development and molecular genetics. In: Dolentium Hominum: The human mind. Proceedings of the fifth international conference organized by the Pontifical Council. Vatican City 1991:28-36.

[55] McEwen BS, Coirini H, Danielson A. Steroid and thyroid hormones modulate a changing brain. J Steroid Biochem Mol Biol 1991; 40:1-14.

[56] Burd GD. Role of thyroxine in neural development of the olfactory system. In: ISOT X Proc of the Tenth Int Symp on Olfaction Taste, GCS ac Press: Oslo 1990:196-205.

[57] Kondo T, Herault Y, Zakany J, Duboule D. Genetic control of murine limb morphogenesis. Relationships with human syndromes and evolutionary relevance. Molec Cell Endocrinol 1998; 40:3-8.

[58] Larsen PR, Davies TF, Hay ID. The thyroid gland. In: Wilson JD, Foster DW, Kronenberg HM, Larsen PR. Eds. Williams Textbook of Endocrinology. WB Saunders Co: Philadelphia 1998:389-515.

[59] Legrand J. Hormones thyroidiennes et maturation du système nerveux central. J Phys Paris 1983; 78:603-52.

[60] Oppenheimer JH, Schwartz HL Molecular basis of thyroid hormone-dependent brain development. Endocrin Rev 1997; 18:462-75.

[61] Forrest D, Erway LC, Ng L, Altschuler R, Curran T. Thyroid hormone receptor $\beta$ is essential for development of auditory function. Nature Genetics 1996; 13:354-7.

[62] Hoskins SG . Metamorphosis of the amphibian eye. J Neurobiol 1990; 21:970-89.

[63] Southard JN, Talamantes F. Placental prolactin-like proteins in rodents: variations on a structural theme Molec Cell Endocrin 1991; 79:C133-C140. 